\title{
III MIĘDZYNARODOWY KONGRES STAREGO TESTAMENTU
}

Z inicjatywy Międzynarodowej Organizacji do Studium Starego Testamentu odbywają się co trzy lata kongresy biblijne poświęcone zagadnieniom archeologii, filologii, historii i literatury Starego Testamentu. Jak wiadomo, pierwszy z tych kongresów odbył się w Kopenhadze w 1953 r., a drugi w Strassburgu w 1956 r. W dniach 31 sierpnia - 5 września br. obradował w Oxfordzie trzeci $\mathrm{z}$ kolei międzynarodowy kongres poświęcony studium Starego Testamentu. Na kongres ten zjechało się przeszło 250 biblistów i orientalistów z całego świata, w tym około 25\% katolików. Do jednego z najlepiej reprezentowanych należał Uniwersytet Hebrajski w Jerozolimie, który wyprawił na kongres aż sześciu profesorów.

W poniedziałek, 31 sierpnia, w glównej auli Examinations School rektor Trinity College przywitał uczestników kongresu w imieniu władz akademickich. Nasteppnie prof. W. F. Albright z Baltimore (USA) podal syntetyczny przeglad dorobku naukowego ostatnich trzech lat $w$ dziedzinie Starego Testamentu, podkreślając zwłaszcza duży wkład uczonych izraelskich na polu archeologii i historii biblijnej. Poczem przewodniczący kongresu, prof. G. R. Driver z Oxfordu, udzielik szereg konkretnych wskazówek odnośnie do przebiegu obrad i prac kongresu.

Następnego dnia, tj. 1 września, usłyszano siedmiu prelegentów. Prof. J. B. Pritchard z Kalifornii (USA) podał wyniki tegorocznych prac wykopaliskowych przeprowadzonych pod jego kierownictwem na miejscu dawnego miasta Gabaonu; zestawił on również te świeżo uzyskane dane archeologiczne $\mathrm{z}$ odnoszącymi się do Gabaonu tekstami biblijnymi. Po przerwie prof. I. Engnell z Uppsali (Szwecja) mówił o aspektach metodologicznych studium Starego Testamentu, podkreślając niezbędność znajomości historii i literatury narodów starożytnego Bliskiego Wschodu i przypominając, że postęp w badaniu Pisma św. będzie możliwy tylko o tyle, o ile bibliści oddadzą się swemu zadaniu w duchu całkowitej bezinteresowności, tj. nie ulegając wpływom jakichś celów apologetycznych czy z góry ustanowionych tez. 
Po poludriu uczestnicy kongresu zwiedzili słynną $\mathrm{Bibl}$ i o teke Bodlejanska. gdzie mieli sposobność obejrzenia manuskryptow i starodruków Biblii oraz innych dzieł hebrajskich i aramajskich. Następnie w auli Examinations School prof. J. Barr z Edynburga (W. Bryt.) wyglosił bardzo ciekawy odczyt o antropomorfizmach i o gatunku literackim teotanii w Starym Testamencie. Po czym prof. E. Jacob ze Strassburga (Francja) uwypuklif podstawy teologiczne etyki starozakonnej. Po przerwie prof. F. P. Castro z Madrytu (Iliszpania) przedstawił próbe wyjaśnienia kryptogramu zawartego w ksiedze zydowskiej Sefer Abisza, a prof. E. Nielsen z Kopenhagi (Dania) podał w ogólnych zarysach swój poglad na pochodzenie i historie Ariki Przymierza. Wreszcie, po kolacji, prof. E. Hammershaimb z Aarhus (Dania) nakreślił czołowe linie ctyki proroków Starego Zakonu.

W trzecim dniu obrod uczestnicy usłyszeli sześć wykładów. Prof. B. Gemser z Groningen (Holandia) uwydatnił identyczność rodzaju literackiego Ksiegi Przypowieści i starneginskiego dzieła zwanego Instrukcjami Onchszeszonqyego. Nastepnie prof. V. Maag z Zurychu (Szwajcaria) staral sie okreslić znaczenie przypisywanej Jahwie godności królewskiej.

Po poludniu prof. G. R. Driver z żone podejmowali uczestników kongresu w parku Nag dale n College. To towarzyskie spotkanie było nadzwyczajna okazja do wznowienia starych znajomości i zawarcia nowych. Po tym przemiłym Garden Party ks. dr L. Alonso-Schökel Tj, profesor Papieskiego Instyiutu Biblijnego w Rzymie, wyglosif odczyt na temat analizy stylistycznej ksiag proroczych, niezbednej jego zdaniem dia nalezytego zrozumienia tych dzieł. Nastepnie prof. J. J. Stamm z Berna (Szwajcaria) podjał próbe wyjaśnienia pochodzenia i znaczenia imienia Dawid, a prof. H. M. Orlinsty z Nowego Jorku podal nowe wriłumaczenie pochodzenia qere i kethib w Biblii mascreckief. Wieczorem prof. B. Mazar z Uniwersytetu Hebrajskiero w Jerozolimie (Izrael) starał się wykazac, że sois miast kaplankich i lewickich w I Kron. 6, 54-81 pochodzi z epoki Salomona. Po referacie zabrał glos prof. W. F. Albright, który uznał wywody prof. B. Mazara za całkiem przekonywajace.

We czwartek, 3 września wygloszono tylko trzy referaty, gdyż tego dnia odbyła się wspólna wycieczka do Windsoru celem zwiedzenia tamtejszego zamku królewskiego. A zatem z rana prof. M. Burrows z Florydy (USA) przeprowadził krytyke urzędowego protestanckiego tłumaczenia Starego Testamentu na jezyl angielski, będącego obecnie w użyciu w Stanach Zjednoczonych. Po referacie prof. M. Noth doręczył prelegentowi w imieniu Orgânizacji specjalny numer czasopisma $\mathrm{Vetus}$ Testamentum dedykowa- 
ny profesorowi M. Burrows z okazji ukończenia 65 roku życia. Następnie ks. prof. A. Diez-Macho z Barcelony (Hiszpania) wykazał antyczne pochodzenie Targumu palestyńskiego przez siebie odnalezionego w Bibliotece Watykańskiej; zdariem prelegenta Targum ten byłby starszy od wszystkich dotychczas znanych Targumów. Wieczorem, po powrocie $z$ wycieczki, prof. A. Dupont-Sommer z Sorbony paryskiej przeprowadził porównanie między qumrańskimi a ewangelicznymi tekstami odnoszącymi się do egzorcyzmów i uzdrowień.

W przedostatnim dniu obrad bardzo wnikliwy i cenny wykład. wygłosił prof. M. Noth z Bonn (NRF), omawiając w świetle ostatnich badań archeologicznych i osiągnięć wspólczesnej krytyki literackiej historię Hebrajczyków w okresie patriarchów i podboju Kanaanu przez szczepy izraelskie. Przy tej sposobności prelegent sprecyzował charakter i znaczenie biblijnych opowiadań etiologicznych. Następnie prof. F. M. Cross z Harvard University (USA) starał się określić na podstawie najnowszych odkryć epigraficznych i studiów filologicznych znaczenie imion Bożych: El Eljon, El Olam, El Szaddaj, Jahwe.

Po południu uczestnicy kongresu mieli możność zwiedzenia zakładów Clarendon Press, jednej z największych drukarni naukowych na świecie. Po tej niezwykle pouczającej, ale męczącej wizycie powrócono do auli konferencyjnej, aby wysłuchać czterech jeszcze wykładów. Najpierw dr S. Segert z Pragi, członek Czechosłowackiej Akademii Nauk, przedstawił kilka zagadnień z problematyki prozodii hebrajskiej, ilustrując przykładami, na życzenie słuchaczy, podane przez siebie rozwiązania. Następnie prof. D. Bardtke z Lipska (NRD) przeprowadził porównania między qumrańskim zwojem Wojny synów światłości z synami ciemności, a znajdującym się w Lipsku kodeksem n. XXVIII, który pod względem treści przedstawia szereg analogii ze zwojem qumrańskim. Prof. Bardtke przygotowuje krytyczne wydanie kodeksu lipskiego wraz z komentarzem. Po krótkiej przerwie prof. R. Meyer z Jeny (NRD) przedstawił w świetle badań współczesnej filologii semickiej hebrajski system czasownikow. Zdaniem prelegenta żadna $z$ naukowych gramatyk języka hebrajskiego nie odpowiada wymogom i osiągnięciom współczesnej filologii. Prof. Meyer opracowuje obecnie nowe wydanie słynnej gramatyki Geseniusa. $\mathrm{Na}$ koniec dr.J. Strugnell, angielski członek zespołu pracującego nad odczytaniem zwojów qümrańskich, przeprowadził analizę nie opublikowanego jeszcze tekstu, który świadczy o istnieniu w gminie qumrańskiej sprecyzowancj nauki o aniołach.

Wieczorem uroczyste przyjęcie zgromadziło w Christ $\mathrm{Church}$ College wszystkich uczestników kongresu. W czasie 
przyjęcia przemówili prof. O. Eissfeldt z Halle (NRD), prof. C. A. Simpson z Oxfordu, prof. P. A. H. de Boer z Leiden (Holandia) i prof. G. R. Driver, przewodniczący kongresu.

Sobota, 5 września, była końcowym dniem obrad. Ostatni referat wygłosił prof. L. Rost z Erlangen (NRF); przeprowadził on studium porównawcze podań przelsazanych przez poszczególne źródia Pięcioksięgu Mojżeszowego, a odnoszące się do czci oddawanej Jahwie przez patriarchów izraelskich. Po odczycie odbyło się plenarne zebranie członków Międzynarodowej Organizacji do Studium Starego Testamentu. $\mathrm{Na}$ wnibsek ustępującego prezesa, prof. W. F. Albrighta, prezesem na następną kadencję został obrany prof. M. Noth z Bonn, któremu powierzono ponadto zorganizowanie w Bonn następnego kongresu międzynarodowego w r. 1962. Zaszły również zmiany personalne w Komitecie Redakcyjnym Vetus Testamentum, oficjalnego czasopisma Organizacji. Na miejsce prof. M. Notha wybrano prof. W. Zimmerli z Göttingen (NRF), a miejsce ustępującego prof. M. Burrows zajął prof. H. G. May ze stanu Ohio (USA.). Nie przyjęto natomiast dymisji ks. prof. H. Cazelles z Paryża. Pozostałymi cziłonkami komitetu, to prof. G. W. Anderson z Durham (W. Bryt.), prof. P. A. H. de Boer z Leiden (Holandia) i prof. E. Hammershaimb z Aarhus (Dania). Do Komitetu Doradczego dobrano prof. M. Burrows, prof. M. Notha i ks. prof. J. Zieglera z Würzburga (NRF).

Następnie prof. P.A.H. de Boer, sekretarz Komitetu Redakcyjnego, odczytał sprawozdanie z trzyletniej działalności wydawniczej Organizacji, podając według poszczególnych krajów ilość prenumeratorów i wspołpracowników Vetus Testamentum oraz wyrażając życzenie, by do redakcji nadsyłano więcej gruntownych artykułów, a mniej krótkich notatek. Zaznaczył on również, że ze względu na ukazanie się specjalistycznego czasopisma $R$ ev u e de Qumran ograniczy się na łamach Vetus Testamentum ilość artykułów poświęconych tematyce qumrańskiej. Pożądanym by był natomiast większy napływ artykułów i sprawozdań z zakresu archeologii palestyńskiej.

Z kolei zabrał głos prof. D.W. Thomas z Cambridge (W. Bryt.), przewodniczacy Komitetu Dorażnego powolanego przez Organizację celem przygotowania krytycznego wydania syryjskiego tiumaczenia Starego Testamentu, zwanego Peszitta. Prof. Thomas zdał sprawozdanie $z$ postępu prac i z trudności wynikłych z powodu dymisji prof. W.D. McHardy, któremu stan zdrowia nie pozwala na dalsze pełnienie funkcji przewodniczącego Komitetu Wykonawczego opracowującego wydanie Peszitty. Zgromadzenie upoważniło więc prof. D.W. Thomas do dobrania nowego przewodniczącego i wice-przewodniczącego. $\mathrm{Na}$ stanowisko przewodniczącego zosta- 
nie prawdopodobnie powołany prof. P. A. H. de Boer, a jego zastepcą begdzie ks. prof. J. Ziegler, względnie prof. E. Hammershainb.

Na koniee zabrał glos prof. G.R. Driver, który zaproponowal między innymi, by plenaine zebranie Organizacji zwróciło się do Uniwersytelu Hebrajskiego w Jerozolimie z prośba o przetiumaczenie na jeden z języków europejskich slynnej juz Encyklopedii Biblijnej zredagowanej w jezyku neo-hebrajskim. Wniosek ten przyjęto jednogłośnie. Prof. Diriver poprosił równiez wszyștkich prelegentów, by nadeslali swe referaty do redakcji $V$ etus Test a m entum przed uplywem miesiąca września. Należy się więc spodziewać rychłego opublikowania odczytów jako ósmego tomu Supplements to Vetus Testamentum.

Warto by podać jeszcze do wiadomości, że w czasie kongresu dowiedziano sie o zmianie na stanowisku naczelnego redaktora zasłużonego i cennego czasopisma biblijnego Zeitschrift ï ür die altestamentliche Wissenschaft: stanowisko chorego niestety prof. J. Hempla objął prof. G. Fohrer z Wiednia.

Louvain

KS. EDW ARD LIPINSKI

\section{ZMIANA TEKSTU MODLITWY O NAWRÓCENIE ZYDÓW W WIELKI PIATEK}

La Documentation Catholique nr 1307 \& 5 lipca 1959 publikuje tekst pisma, które Kongregacja Obrzędów przekazała biskupom francuskim:

Moca najwyższego rczporzadzenia Jego Świątobliwości Papieża Jana XXIII modlitwa liturgiczna na Wielki Piątek ,Pro conversione Iudaeorum" została zmieniona nastẹpująco:

Oremus et pro Iudaeis: ut Deus et Dominus noster auferat velamen de cordibus eorum; ut et ipsi agnoscant Iesum Christum Dominum nostrum.

Oremus. - Flectamus genua. - Levate.

Omnipotens sempiterne Deus, qui Iudaeos etiam a tua misericordia non repellis: exaudi preces nostras, quas pro illius populi obcaecatione deferimus; ut agnita veritatis tuae luce, quae Christus est, a suis tenebris eruantur. Per eumdem Dominum... 